\title{
Can Z-Score Model Predict Listed Companies' Failures in Italy? An Empirical Test
}

\author{
Massimiliano Celli ${ }^{1}$ \\ ${ }^{1}$ Department of Management and Law, Roma TRE University, Italy \\ Correspondence: Massimiliano Celli, Department of Management and Law, Roma TRE University, Rome, Via \\ Silvio D’Amico 77, 00145, Italy. E-mail: massimiliano.celli@uniroma3.it
}

Received: December 19, 2014

Accepted: February 2, 2014

Online Published: February 27, 2015

doi:10.5539/ijbm.v10n3p57

URL: http://dx.doi.org/10.5539/ijbm.v10n3p57

\begin{abstract}
The Altman Z-score model for predicting bankruptcy of businesses was constructed and fine-tuned in the USA in 1968 and updated in 1999. It is therefore possible that its results cannot be extended to non-Anglo-Saxon countries in today's context. This paper ascertains if the Z-score can correctly predict the failure of industrial listed companies in Italy. First, we have analyzed the theoretical and practical characteristics of the original $Z$-score model and we highlight some of its potential shortcomings. Second, we have examined a sample of 102 industrial companies, quoted on the Italian Stock Exchange in the period 1995-2013 - 51 companies had had their shares permanently suspended or delisted because of a default, whereas the remaining 51 companies, which have been selected based on same core business and year of data collection, did not go bankruptcy or had their shares permanently suspended. We investigated whether the Z-score model could have predicted the default of the firms in the sample for up to three years earlier, with a degree of accuracy and reliability comparable to the one obtained by Altman (and by many other authors) in the tests performed nowadays in the U.S. and Anglo-Saxon contexts. We found that the Z-score works effectively and performs well in predicting failures of Italian firms, although with a slightly lower degree of reliability when applied to Anglo-Saxon companies. Therefore, we conclude that the Z-score can be applied to the Italian context, provided that some critical points illustrated in this study are taken into account.
\end{abstract}

Keywords: Z-score, Altman, failure prediction models

\section{Introduction}

A largely used statistical model for predicting the failure of businesses within a few years before bankruptcy is Altman's Z-score developed in 1968, with reference to industrial companies listed on the U.S. stock market. The model is based on an array of financial ratios in a multivariate context and on a discriminated model.

Even though this statistical failure-prediction model has gone through a number of revisions and modifications in order to be applied also to companies not listed on regulated markets (Note 1), as well as to small and medium entities and non-industrial businesses (service companies rather than financial ones), we believe its original version still plays an important role nowadays for practitioners throughout the world.

The reason of its success is in the fact that the Z-score model is easy to understand and can be used by anyone, even in the absence of adequate knowledge and skills in the field of business insolvency risk analysis. As we will see further on, the model uses easily obtainable data, from both balance sheets and statements as well as mean market share values relative to the reference period. Besides, the Z-score model is highly reliable in measuring the default potential of industrial business listed on the U.S. market.

This article aims to verify whether the Z-score model in its original version (constructed by Altman in 1968 and modified by the same author in 1993), can be used to assess bankruptcy potential for industrial businesses listed on regulated market in countries different from the U.S. (and different from Anglo-Saxon countries in general). Indeed, we tested whether the model can be applied to the context of Italian industrial businesses listed on the Borsa di Milano (Italian stock market).

Specifically, we used a sample of 102 industrial companies: 51 companies whose shares were permanently suspended over the years 1995-2013 or delisted because of a default (which is revealed by one of the following legal procedures: business failure, admission to Italian extraordinary administration proceedings (EA) and 
winding up). As a control sample, we used 51 non-delisted companies with comparable size of total assets selected from the same industrial sector and same year of data collection. The model was tested on the businesses in the sample by verifying, ex-post ("yesterday for today"), whether the impending business failures could have been predicted three years earlier and with reasonable precision using the Z-score model (Note 2).

It has been ascertained that the $Z$-score model can predict the distress of industrial companies listed on the Italian Stock Exchange (Borsa di Milano). The success and accuracy rates shown by the model when applied to the Italian context are indeed fairly high, and the corresponding error rates quite low.

The article is organized as follows. The following section provides a literature review of the topic in object. In section 3 we illustrate the study objectives. In section 4 we analyze the characteristics of the Z-score model with special attention to the components of the statistically discriminating function and to the definition of the cut-off points needed to apply the model, as well as to the relevant critical aspects. Concerning these critical aspects, we will see how they may compromise (or limit) the ability of the model in detecting bankruptcy potentials in specific environments and under specific circumstances. In section 5, we show the research methodology and discuss the results of the application of the Z-score to Italian industrial quoted business to ascertain if the model can predict failures of companies in Italy with a similar success rate as in the U.S. and, more in generally, in all Anglo-Saxon countries. In section 6, we draw conclusions on the topic.

\section{Literature Overview}

Financial insolvency of big businesses, a typical and dramatic phenomenon that affects the economic and social structure of a country, has been the object of numerous studies that aimed to detect the causes and predict its future happening with reasonable accuracy.

Between the 70s and the 80 s of last century a branch of studies was developed to try predicting insolvency by means of statistical methodologies based on the use of economic and financial indicators (Altman, 1968, 2002; Deakin, 1972; Libby, 1975; Balwind \& Glezen, 1992; Altman, Hartzell, \& Peck, 1995; Beaver, Correia, \& McNichols, 2011; Fitzpatrick \& Ogden, 2011; Lina, Liangb, \& Chenc, 2012; Delena, Kuzeyb, \& Uyarb, 2013).

In the 1990s, the discriminant analysis was complemented by studies characterized by probit analysis, the use of neural networks, logit models and other innovative methodologies (Gilbert, Menon \& Schwarts, 1990; Altman, Marco, \& Varetto, 1994; Johnsen \& Melicher, 1994; Mokhatab Rafieia, Manzarib, \& Bostanian, 2011). For a review of the international literature on the topic, we refer to the work of Bellovary, Giacomino \& Akers (2007), a comprehensive summa of theoretical contributions between 1996 to 2007 (Altman, Danovi, \& Falini, 2013).

As for the Z-score (and its variants-Note 1) its predictive ability with reference to businesses settled in countries other than the U.S. (and, more in general, Anglo-Saxon) has been censured by some authors, given that the model was specifically constructed and fine-tuned by Altman with reference to companies listed on the U.S. market (Grice \& Ingram, 2001; Grice \& Dungam, 2001; Ooghe \& Balcaen, 2006; Kapadia, 2011).

With specific regard to the Italian today's context, neither business scholars nor researchers have yet analyzed if the Z-score model can correctly predict the distress of industrial listed companies as well as measure the pertinent failure risk.

\section{Study Objectives}

The Z-score model has been constructed and fine-tuned in the U.S. in 1968 and modified in 1999, so it is possible that its predictive ability with respect to companies listed on markets other than the U.S. (and, more in general, Anglo-Saxon markets) could be lower than the accuracy rate tested by Altman and other authors in nearly forty years of experiments.

In our study, we apply the model to Italian industrial listed companies trying to ask the following questions:

- Is the Z-score effective in classifying industrial companies listed on Italian Stock Exchange (Borsa di Milano) into failed or non-failed groups?

- Is the degree of accuracy and reliability of the Z-score applied to Italian industrial listed companies comparable to the one obtained by Altman in the tests performed in the U.S.?

- How many years prior to distress does the Altman Z-score give high correct prediction rates and low error rates in predicting bankruptcy of industrial companies listed on the Italian Stock Exchange? 


\section{Characteristics and Critical Aspects of the Z-Score}

\subsection{Characteristics}

The Z-score model was developed in order to combine the traditional index analysis with rigorous statistical techniques. Similar to the majority of models used for early diagnosis of default risk of businesses, it is based on multivariate discriminant analysis. Such method allows classification - with very low error probability-of a set of statistical units into two or more groups identified beforehand (in this particular case, financially healthy businesses and default risk businesses) on the basis of some known variables (discriminant variables) that are observed in the same units. Groups have the same homogeneous characteristics for the elements included in each group, and heterogeneous characteristics for the elements belonging to different groups: if an element is identified by the model as having similar characteristics as a specific group, it will be classified through a comparative and associative process (Danovi \& Quagli, 2012).

The aforementioned variables are: balance sheets indicators selected according to their frequency of use in the literature, their quantitative relevance and their mean value on the equity market. Each variable in the multivariate function is multiplied by different ponderable factors: the final result of the function is called score and assigns the statistical unit examined to one group rather than to another.

At first, Altman identified a list of 22 possible ratios that he considered more adequate to predict future businesses crisis based on empirical tests. Such ratios further merged into five macro classes, each of them able to provide comprehensive information about the different structural dimensions of a business: liquidity, profitability, leverage, solvency and invested capital. Finally, after numerous tests, Altman chose the five best performing ratios because of their ability to predict potential future failures when they were applied together.

The last version (1993) of the $Z$-score model is the following:

$$
Z=1,2 X_{1}+1,4 X_{2}+3,3 X_{3}+0,6 X_{4}+1,0 X_{5}
$$

The independent variables (ratios), symbolized by $X_{n}$, are:

- $\mathrm{X}_{1}=$ Working Capital / Total Assets (WC/TA). This liquidity index value tends to decrease under crisis conditions, provided that the increasingly negative results involve a downturn in the value of current activities;

- $\mathrm{X}_{2}=$ Retained Earnings / Total Assets (RE/TA). It measures the ability of a firm of self-financing, that is of investing the income gained periodically - totally or in part - in new business projects;

- $\mathrm{X}_{3}=$ Earnings Before Interests and Taxes / Total Assets (EBIT/TA). This index measures returns on any type of invested capital (risk or financial investment) in the business;

- $\mathrm{X}_{4}=$ Market Value of Equity / Book Value of Total Liabilities (MVE/TL). This particular index introduces the discriminant function (otherwise based on balance sheet indicators only). This parameter takes into account the market value of owned capital, i.e. common stock representing the business' total assets, and is calculated on the day of each closure of accounts. The value of total liabilities, instead, is calculated based on management data and includes both long and short term financing;

- $\mathrm{X}_{5}=$ Sales / Total Assets (S/TA). This index calculates the ability of total assets to generate earnings (i.e. how often invested capital produces cash returns collected on sales).

In order to apply the Z-score for measuring the default risk of a specific company, one needs to solve the linear equation above by simply replacing each independent variable with the corresponding balance sheet indicators and the market value of own capital. The score obtained is then compared to a threshold value (cut-off value) set beforehand, on condition that the companies under examination will be classified as financially healthy or at default risk only after this comparison.

Altman set the cut-off value of the Z-score model at 2,675. A score above this value means that the company is potentially healthy, whereas a score below this value means that the company is probably headed for bankruptcy. The author also introduces the concept of a grey area ('uncertainty area') with a Z-score between 1,81 (below which companies are definitely exposed to default) and 2,99 (above this the risk of default is equal to zero). In this case, it is impossible to make a clear assessment as to the operating difficulties of the company (which may be inherent in the company or likely to lead to default), and further data and information are needed in order to classify the company in any of the two groups aforementioned.

To sum up, the situation of companies can be classified as:

- Financially healthy, if $Z>2,99$; 
- Uncertain, with scores between 1,81 and 2,99 , and specifically:

○ Low default probability, if $2,675<\mathrm{Z}<2,99$;

- Middle - high probability of default, if $1,81<Z<2,675$;

- At major default risk, if $\mathrm{Z}<1,81$.

\subsection{Critical Aspects}

As for the theoretical limitations of this model, we believe that, in primis, they lie in the fact that the Z-score has been constructed for and tested by Altman on U.S. industrial businesses. Its high default-predictability rate is therefore applicable to the American (and broadly speaking Anglo-Saxon) context. For companies quoted on different markets (i.e., the Italian market that we analyze in this paper) it might be advisable to proceed to a preliminary validation of the model and, if necessary, carry out some modification (with respect to ponderable factors in particular) in order to tailor the model to the characteristics of the companies that are being investigated and to the economic systems in which they operate (Begley, Ming \& Watts, 1996).

It is worth pointing out that the Z-score effectiveness in classifying US quoted companies has been tested many times (Alkhatib \& Al Bzour, 2011) at 95\% one year prior to default (year -1), at 83\% two years prior to default (year -2) and at $62 \%$ three years prior to default (year -3 ). However, for companies quoted on the Greek market, for example, the accuracy rate of the model is very different (Gerantonis, Vergos, \& Christopoulos, 2009): the degree of correct classification is $66 \%$ in the year before default (year -1 ), and goes gradually down to $52 \%$ and to $39 \%$ in year two (year -2) and three (year -3) before default. For companies quoted on the Jordanian market, instead, the accuracy rate of the model is still different (Alareeni \& Branson, 2013): the Z-score effectiveness has been tested at $87 \%$ one year prior to default (year -1 ), at $94 \%$ two years prior to default (year -2 ) and at $89 \%$ three years prior to default (year -3).

Besides, as already mentioned above, almost all independent variables in the discriminant function are based on balance sheet data. On the one hand, this makes the Z-score of easy and immediate use; on the other hand, the data available might not be completely objective (or even worse, be totally false), since the managers of the investigated companies may have adopted budget policies aimed at hiding the ongoing or forthcoming crisis. This is likely to affect the reliability of the model to a greater or lesser degree-it is understood that similar behaviors should be immediately made known and sanctions applied by public and private control bodies. The use of rigorous statistical methodologies to assess the degree of solvency of businesses does not allow overcoming the intrinsic limitations of balance sheet values; if they are altered, the accuracy of the assessment of the statistical models - which are based on these data - is inevitably compromised.

Finally, the discriminant function of the Z-score is significantly unbalanced with regard to business profitability (ponderable factor equal to 3,3 ) the variable that may potentially predict the crisis of the company. On the one hand, this approach may be justified, if we posit that the continuation of a firm over time depends also on its ability to obtain returns on the invested capital. On the other hand, it should be pointed out that a firm with poor profitability is not necessarily at default risk, provided that its financial position and cash flows appear to be safe at present and in the future.

On the contrary, we do not share the criticism according to which the balance sheet indicators are descriptive in nature and that they lack predictability even when they are part of a discriminant function, and therefore that they can only describe a condition of insolvency and not predict it (Scott, 1981; De Andrés, Landajo, \& Lorca, 2012), thus being a tool to discriminate ex-post but not ex-ante. The Z-score only supplies ex ante classification, with a relatively low level of error, of a set of statistical units into two or more groups (both healthy businesses and at default risk) on the basis of known characteristics and compares the score obtained from the business under investigation with the scores of sample businesses. The role of the Z-score is to identify a trend that combines the values of the analyzed variables in the years prior to the crisis, for both healthy businesses and the defaulted ones; consequently, it appears to be a descriptive and comparative approach rather than a probabilistic one, as Altman himself pointed out (Altman, Danovi, \& Falini, 2013). In this regard, the usefulness of the Z-score as a way of "warning" rather than predicting should not be questioned (Åstebro \& Winter, 2012).

\section{Study Design and Results}

\subsection{Research Methodology and Data Design}

This study aims at verifying the reliability of the Z-score model in predicting future defaults of industrial companies quoted on the Italian Stock Exchange (Borsa Italiana S.p.A.). The test was performed on a set of 51 companies, whose shares were permanently suspended or delisted in the period 1995-2013, following 
irreversible crises.

The complete list of companies whose shares are permanently suspended or delisted is supplied yearly by Borsa Italiana S.p.A. Obviously, we wanted to make sure that the cause of permanent suspension of quoted share, or delisting, was business failure, admission to Italian extraordinary administration proceedings (EA) and winding-up exclusively (Note 3), in order to avoid including companies that were delisted, or suspended from listing, for reasons other than crisis-related. For this purpose we collected data and information from financial databases, such as Il Sole24Ore, Aida, Borsa Italiana S.p.A. and Italian Market Surveillance Authority (Consob). Moreover, companies not delisted or permanently suspended from listing - although going through a time of more or less overt financial difficulty-were not included in the sample.

To this end, in our opinion (as already mentioned in Note 2) the delisting, or the permanent suspension from quotation, is a quite accurate proxy for businesses failure in Italy. Indeed, if it is hard to assess the distress of a business objectively, and to assign a value to the crisis itself, delisting or permanent suspension are, instead, automatically attributed by the Market Surveillance Authority (Consob) when a quoted company is subject to one of the aforementioned legal procedures (failure, winding up and extraordinary administration), which constitute the legal outcome of a status of crisis.

Likewise previous studies on the topic at stake (Gerantonis, Vergos, \& Christopoulos, 2009; Alareeni \& Branson, 2013), the examined sample consists of 102 companies listed on the Italian Stock Exchange (Borsa Italiana S.p.A.): we applied the Z-score model to 51 defaulted companies (thus delisted or permanently suspended) as well as to 51 non-defaulted companies (thus non-delisted or permanently suspended), each of these selected on the basis of the same core business and year of data collection.

Additionally, the selection of all the 102 companies within the sample was performed according to the following requirements:

- Balance sheets and income statements available for the three years prior to delisting or permanent suspension from quotation. The financial reports used are annual and cover the period 1992-2012. The financial data were collected from Aida database and Borsa Italiana S.p.A.;

- The market value of each company has been taken on December 31 of each year in the three years prior to delisting. Prices were taken from the periodical reports of Borsa Italiana S.p.A.;

- The examined companies belong to the industry sector (with the exception of No. 2 airlines). Banks, insurance and financial companies are excluded.

The degree of reliability of the Z-score was measured through an ex-post approach, i.e. we verified if the model would have been able to foresee the trend of the operating difficulties of each company. Specifically, for each company in the sample, the discriminant function was applied to the balance sheet values and the market values in the three years prior to delisting (or prior to suspension from listing) in order to ascertain if the Z-score would have predicted the future of those businesses accurately. By comparing the data obtained through the statistical model and what actually happened to the companies under investigation (if they were delisted because of default) it is possible to precisely ascertain the accuracy rate of the model.

Following we applied the Z-score model to each company of the sample (No. 102 with reference to the period 1995-2013) for consecutive three years. In order to improve the comprehensibleness and helpfulness of our study we also calculated some indicators, likewise other studies on the topic at stake (Alareeni \& Branson, 2013). Specifically:

- Class A correct prediction rate is defined as the number of delisted or permanently suspended companies correctly predicted as delisted or permanently suspended by the model, divided by the total number of delisted or permanently suspended companies in the study sample (No. 51);

- Class B correct prediction rate is defined as the number of non-delisted or non-permanently suspended companies correctly predicted as non-delisted or non-permanently suspended by the model divided by the total number of non-delisted or non-permanently suspended companies in the study sample (No. 51);

- Overall success rate is the number of companies correctly classified (delisted or permanently suspended and non-delisted or non-permanently suspended) divided by the total number of companies in the study sample (No. 102);

- Class A error rate is the ratio of the number of delisted or permanently suspended companies incorrectly classified as non-delisted or non-permanently suspended by the model to the total number of companies delisted or permanently suspended in the sample; 
- Class B error rate is the ratio of the number of non-delisted or non-permanently suspended companies incorrectly classified as delisted or permanently suspended by the model to the total number of non-delisted or non-permanently suspended companies in the sample;

- Overall error rate is the number of companies incorrectly classified divided by the total number of companies in the study sample (No. 102).

\subsection{Study Results}

In order to verify the reliability of the model, we compared the scores obtained by each firm in the sample during the three years prior to delisting to the cut-off value $(2,675)$ set by Altman. The companies whose shares have been delisted or permanently suspended over the period 1995-2013 because of failure, winding up or admission to extraordinary administration regime, should fall within the score range expected for these companies (e.g. smaller than 2,675, and a fortiori than 1,81, which represents the lower bound of the grey area); whereas non-delisted companies should fall within the score range expected for those companies (e.g. higher than 2,675).

As for the companies whose shares were delisted or permanently suspended in the period 1995-2013, the application of the Z-score showed the following results:

Table 1. Z-score prediction statistics for delisted companies (No. 51)

\begin{tabular}{|c|c|c|c|c|}
\hline Year & $\begin{array}{c}\text { Correctly Classified } Z<2,675 \\
\text { (of which } Z<1,81 \text { ) }\end{array}$ & $\begin{array}{c}\text { Class A Correct Classification Rate } \\
\text { (of which } \mathrm{Z}<1,81 \text { ) }\end{array}$ & $\begin{array}{c}\text { Incorrectly Classified } Z>2,675 \\
\text { (of which } Z>2,99 \text { ) }\end{array}$ & $\begin{array}{l}\text { Class A Error Rate } \\
\text { (of which } \mathrm{Z}>2,99 \text { ) }\end{array}$ \\
\hline \multirow{2}{*}{$\mathrm{T}-1$} & 43 & $84,3 \%$ & 8 & $15,7 \%$ \\
\hline & (37) & $(72,5 \%)$ & $(-)$ & $(-)$ \\
\hline \multirow{2}{*}{$\mathrm{T}-2$} & 36 & $70,5 \%$ & 15 & $29,5 \%$ \\
\hline & (28) & $(54,9 \%)$ & $(-)$ & $(-)$ \\
\hline \multirow{2}{*}{$\mathrm{T}-3$} & 24 & $47,1 \%$ & 27 & $52,9 \%$ \\
\hline & (11) & $(21,5 \%)$ & (3) & $(5,8 \%)$ \\
\hline
\end{tabular}

As is shown in Table 1, Class A correct prediction rate of the Z-score was $84,3 \%, 70,5 \%$ and $47,1 \%$ for predictions within the first (T-1), second (T-2), and third (T-3) year prior to the year of delisting or permanent suspension (T), respectively. With reference to the lower bound of grey area (score $<1,81$ ) in particular, Class $A$ correct prediction rate was $72,5 \%, 54,9 \%$ and $21,5 \%$ for predictions within the first (T-1), second (T-2), and third (T-3) year prior to the year of delisting or permanent suspension (T), respectively. Class A error rate was $15,7 \%, 29,5 \%$ and $52,9 \%$ within the first (T-1), second (T-2) and third (T-3) year prior to the year of delisting or permanent suspension (T), respectively. As for the higher bound of grey area (score $>2,99$ ), Class A error rate was $0 \%, 0 \%$ and $5,8 \%$ within the first (T-1), second (T-2) and third (T-3) year prior to the year of delisting or permanent suspension $(\mathrm{T})$, respectively.

Accordingly, the Z-score shows a good capacity in predicting failures of companies, at least one year before the company is delisted or permanently suspended from quotation, but its reliability decreases (of course) as the prediction time horizon increases. In any case, the observed rates are lower than the original Altman results of few per cent points, especially for predictions within the first (T-1) and the second (T-2) year prior to the year of delisting $(\mathrm{T})$. Consequently we conclude that the $Z$-score can forecast future crisis-related delisting or permanent suspension of companies, with acceptable error rates and good classification accuracy.

It has been observed that in a specific, limited number of cases (No. 3), the model is less precise as the year of delisting approaches. This is probably explained by the fact that the managers of the companies try not to disclose the financial distress status, and they do even more so as the situation becomes more critical. The symptoms of a crisis are therefore "hidden" by adopting balance sheet account policies that are often "legally" illegal, aimed at altering the cash flow statements and, consequently, the values of the indicators in the Z-score.

As for non-delisted or non-permanently suspended companies in the period 1995-2013, the application of the model gave the following classification: 
Table 2. Z-score prediction statistics for non-delisted companies (No. 51)

\begin{tabular}{ccccc}
\hline Year & $\begin{array}{c}\text { Correctly Classified Z>2,675 } \\
\text { (of which Z>2,99) }\end{array}$ & $\begin{array}{c}\text { Class } \mathbf{B} \text { Correct Classification Rate } \\
\text { (of which Z>2,99) }\end{array}$ & $\begin{array}{c}\text { Incorrectly Classified Z<2,675 } \\
\text { (of which Z<1,81) }\end{array}$ & $\begin{array}{c}\text { Class B Error Rate } \\
\text { (of which Z<1,81) }\end{array}$ \\
\hline \multirow{2}{*}{$\mathrm{T}-1$} & 46 & $90,1 \%$ & 5 & $9,9 \%$ \\
& $(40)$ & $(78,4 \%)$ & $(-)$ & $(-)$ \\
$\mathrm{T}-2$ & 43 & $84,3 \%$ & 8 & $15,7 \%$ \\
& $(35)$ & $(68,6 \%)$ & $(1)$ & $(1,9 \%)$ \\
$\mathrm{T}-3$ & 44 & $86,2 \%$ & 7 & $13,8 \%$ \\
& $(32)$ & $(62,7 \%)$ & $(-)$ & $(-)$ \\
\hline
\end{tabular}

As it is shown in Table 2, the Z-score performs well in classifying the majority of non-delisted or non-permanently suspended companies in the panel, even in longer time horizons. Class B correct prediction rate was $90,1 \%, 84,3 \%$ and $86,2 \%$ within the first (T-1), second (T-2) and third (T-3) year prior to the reference year (T), respectively. As for the higher bound of grey area (score $>2,99)$, Class $B$ correct prediction rate was $78,4 \%, 68,6 \%$ and $62,7 \%$ for predictions within the first (T-1), second (T-2), and third (T-3) year priors to the reference year (T), respectively. As for Class B error rate, it was 9,9\%, 15,7\% and 13,8\% within the first (T-1), second (T-2) and third (T-3) year prior to the reference year (T), respectively. With regard to the lower bound of grey area (score $<1,81$ ), Class B error rate was $0 \%, 1,9 \%$ and $0 \%$ for predictions within the first (T-1), second (T-2), and third (T-3) year prior to the reference year (T), respectively.

With regards to aggregated data of all the companies (delisted or permanently suspended and non-delisted or non-permanently suspended), when compared to the cut-off point of 2,675 the Overall success rate and the Overall error rate of the Z-score are illustrated below:

Table 3. Z-score prediction statistics for all companies (No. 102)

\begin{tabular}{ccccc}
\hline Year & $\begin{array}{c}\text { Correctly Classified } \\
\text { Cut off } \mathbf{2 , 6 7 5}\end{array}$ & Overall Success Rate & $\begin{array}{c}\text { Incorrectly Classified } \\
\text { Cut off 2,675 }\end{array}$ & Overall Error Rate \\
\hline T-1 & 89 & $87,3 \%$ & 13 & $12,7 \%$ \\
$\mathrm{~T}-2$ & 79 & $77,5 \%$ & 23 & $22,5 \%$ \\
$\mathrm{~T}-3$ & 68 & $66,6 \%$ & 34 & $33,3 \%$ \\
\hline
\end{tabular}

\section{Conclusions}

Since 1968, many authors and practitioners have used the Z-score model as a tool for predicting failure of companies and measuring the related risk of bankruptcy, especially in the Anglo-Saxon countries.

In this study, the relative performance of the multivariate function elaborated by Altman in discriminating between failed and non-failed firms is examined with regard to companies quoted on Italian Stock Market (Borsa di Milano).

We found that the Z-score degree of reliability is relatively high and still works quite adequately in predicting listed industrial company failure in Italy. It proved a precious tool in the detection of company operating and financial difficulties up to 3 years before the default. Class $A$ and $B$ correct prediction rates of the model in the three years prior to delisting or permanent suspension from quotation were acceptable, and corresponding error rates were low.

As for time distribution of errors, we found the efficiency of the model improves as the year of delisting comes closer. The explanation is purely intuitive: predictions are more accurate when they concern a time span that is closer to the time when financial distress occurs, whereas the error risk is higher when the reference time horizon increases.

An exception to this is not statistically significant: the reliability of the model seems to be weaker for a limited number of companies (No. 3) in the T-2 period. We think that this anomaly should be interpreted in the light of the balance sheet policies (which often result in the issuing of forged documents, a practice that is punished by law) that the managers pursue in order to disguise a forthcoming or already on-going financial distress status. Moreover, the anomaly is in contrast with the numerous evaluations supplied by Altman himself (as well as by 
other authors who have confirmed the trustworthiness of the model over the years) with regard to companies quoted on Anglo-Saxon markets. Based on such evaluation, all tested companies show a common downward trend of the model's error ratio as the year of default approaches.

Besides, the predictive ability of Z-score in the Italian context tends to be inferior to the ability measured by Altman (and other researchers) in about forty years of experiments on industrial businesses quoted on Anglo-Saxon markets (equal to an average of $70 \%$ on annual basis). To our view, such difference is "physiological", since the model was constructed and fine-tuned with reference to companies and markets that are qualitatively different from the Italian ones.

To sum up, the Z-score model has indisputable potential to correctly classify businesses in financial distress starting from the third year prior to default; therefore, the model has to be considered as a general "warning" tool-with the limitations we have highlighted in this article - that is fairly accurate (and easy to use) even when applied to different spatio-temporal environments.

\section{Limitations and Recommendations}

Our study has some limitations, similar to other empirical studies on the topic at stake. Specifically, the Z-score degree of accuracy and reliability obtained in the tests performed in Italy on industrial listed companies (banks, insurance and financial companies were excluded) could not be generalized to other countries, even to countries with common environmental factors. Therefore, for companies quoted on different markets it might be advisable to proceed to a preliminary validation of the model.

\section{References}

Alareeni, B., \& Branson, J. (2013). Predicting listed companies' failure in Jordan using Altman models: A case study. International Journal of Business and Management, 8(1), 113-126. http://dx.doi.org/10.5539/ijbm.v8n1p113

Alkhatib, K., \& Al Bzour, A. E. (2011). Predicting Corporate Bankruptcy of Jordanian Listed Companies: Using Altman and Kida Models. International Journal of Business and Management, 6(3). http://dx.doi.org/10.5539/ijbm.v6n3p208

Altman, E. (1968). Financial ratios. Discriminant analysis and the prediction of corporate bankruptcy. The Journal of Finance, 23(4), 589-609. http://dx.doi.org/10.1111/j.1540-6261.1968.tb00843.x

Altman, E. (1993). Corporate financial distress and bankruptcy (2nd ed.). Wiley \& Sons, New York.

Altman, E. (2002). Revisiting credit scoring models in a Basel 2 environment. In M. Ong (Ed.), Credit rating: methodologies: Rationale and default risk. Risk Book, London.

Altman, E., Haldeman, R., \& Narayanan, P. (1977). Zeta analysis: a new model to identify bankruptcy risk of corporations. Journal of Banking \& Finance, 1(1), 29-54. http://dx.doi.org/10.1016/0378-4266(77)90017-6

Altman, E., Marco, G., \& Varetto, F. (1994). Corporate distress diagnosis: Comparisons using linear discriminant analysis and neural networks (the Italian experience). Journal of Banking \& Finance, 18(3), 505-529. http://dx.doi.org/10.1016/0378-4266(94)90007-8

Altman, E., Hartzell, J., \& Peck, M. (1995). Emerging markets corporate bonds: a scoring system. Salomon Brothers Inc., New York. http://dx.doi.org/10.1007/978-1-4615-6197-2

Altman, E., Danovi, A., \& Falini, A. (2013). Z-score models' application to Italian companies subject to extraordinary administration. Journal of Applied Finance, 23(1), 24-37.

Åstebro, T., \& Winter, J. K. (2012). More than a Dummy: The Probability of Failure, Survival and Acquisition of Firms in Financial Distress. European Management Review, 9(1), 1-17. http://dx.doi.org/10.1111/j.1740-4762.2011.01024.x

Baldwin, J., \& Glezen, G. (1992). Bankruptcy prediction using quarterly financial statement data. Journal of Accounting, Auditng \& Finance, 3(7), 269-285. http://dx.doi.org/10.1177/0148558X9200700301

Beaver, W. H., Correia, M. M., \& McNichols, M. (2011). Financial statement analysis and the prediction of financial distress (pp. 1-323). Boston: Now Publishers Inc.

Begley, J., Ming, J., \& Watts, S. (1996). Bankruptcy classifications errors in the 1980s: an empirical analysis of Altman's and Ohlson's models. Review of Accounting Studies, 1(4), 267-284. http://dx.doi.org/10.1007/bf00570833 
Bellovary, J. L., Giacomino, D. E., \& Akers, M. D. (2007). A review of bankruptcy prediction studies: 1930 to present. Journal of Financial Education, 33(4), 1-43.

Danovi, A., \& Quagli, A. (2012). Crisi aziendali e processi di risanamento (pp. 154-167). Ipsoa, Milano.

Deakin, E. (1972). A discriminant analysis of predictors of business failure. Journal of Accounting Research, 10(3), 167-179. http://dx.doi.org/10.2307/2490225

De Andrés, L., Landajo, M., \& Lorca, P. (2012). Bankruptcy prediction models based on multinorm analysis: An alternative to accounting ratios. Knowledge-Based Systems, 30(6), 67-77. http://dx.doi.org/10.1016/j.knosys.2011.11.005

Delena, D., Kuzeyb, C., \& Uyarb, A. (2013). Measuring firm performance using financial ratios: A decision tree $\begin{array}{lllll}\text { approach. } & \text { Expert }\end{array}$ http://dx.doi.org/10.1016/j.eswa.2013.01.012

Fitzpatrick, J., \& Ogden, J. P. (2011). The Detection and Dynamics of Financial Distress. International Review of Finance, 11(1), 87-121, http://dx.doi.org/10.1111/j.1468-2443.2010.01119.x

Gerantonis, N., Vergos, K., \& Christopoulos, A. G. (2009). Can Altman Z-score models predict business failures in Greece? Research Journal of International Studies, 12(10), 21-28.

Gilbert, L., Menon, K., \& Schwartz, K. (1990). Predicting bankruptcy for firms in financial distress. Journal of Business Finance and Accounting, 17(1), 161-171. http://dx.doi.org/10.1111/j.1468-5957.1990.tb00555.x

Grice, J., \& Ingram, R. (2001). Tests of generalizability of Altman's bankruptcy prediction model. Journal of Business Research, 54, 53-61. http://dx.doi.org/10.1016/S0148-2963(00)00126-0

Grice, J., \& Dugan, M. (2001). The limitations of bankruptcy prediction models. Some cautions for the researcher. Review of Quantitative Finance and Accounting, 17, 151-166. http://dx.doi.org/10.1023/A:1017973604789

Johnsen, T., \& Melicher, R. W. (1994). Predicting corporate bankruptcy and financial distress: information value added by multinomial logit models. Journal of Economics and Business, 46(4), 269-286. http://dx.doi.org/10.1016/0148-6195(94)90038-8

Kapadia, N. (2011). Tracking down distress risk. Journal of Financial Economics, 102(1), 167-182. http://dx.doi.org/10.1016/j.jfineco.2011.05.004

Libby, R. (1975). Accounting ratios and the prediction of failure: some behavioral evidence. Journal of Accounting Research, 13(1), 150-161.

Lina, F., Liangb, D., \& Chenc, E. (2011). Financial ratio selection for business crisis prediction. Expert Systems with Applications, 38(12), 15094-15102. http://dx.doi.org/10.1016/j.eswa.2011.05.035

Mokhatab, R. F., Manzarib, S. M., \& Bostanian, S. (2011). Financial health prediction models using artificial neural networks, genetic algorithm and multivariate discriminant analysis. Expert Systems with Applications, 38(8), 10210-10217, http://dx.doi.org/10.1016/j.eswa.2011.02.082

Ooghe, H., \& Balcaen, S. (2006). 35 years of studies on business failure: an overview of the classic statistical methodologies and their related problems. The British Accounting Review, 38(1), 63-93. http://dx.doi.org/10.1016/j.bar.2005.09.001

Scott, J. (1981). The probability of bankruptcy: a comparison of empirical predictions and theoretical models. Journal of Banking and Finance, 5(3), 317-344. http://dx.doi.org/10.1016/0378-4266(81)90029-7

Xiaoa, Z., Yanga, X., Panga, Y., \& Dangb, X. (2012). The prediction for listed companies' financial distress by using multiple prediction methods. Knowledge-Based Systems, 26(2), 196-206. http://dx.doi.org/10.1016/j.knosys.2011.08.001

\section{Notes}

Note 1. In 1977 Altman, Haldeman \& Narayanan introduced the Zeta ${ }^{T M}$ model, in order to improve the classification and prediction accuracy of the original Z-score. The differences between the Z-score and Zeta ${ }^{T M}$ are in the dissimilar compositions of some of the discriminant variables and in the different value of the market parameters. The latter cannot, however, be disclosed since the model is the property of Wood, Struthers \& Winthrop. In 1993, Altman himself constructed the Z'-score, in which the original model is modified in order to assess the distress of companies not listed on regulated markets (such as Small-Medium Entities). In 1995, the 
model Z"'-score (Altman, Hartzell \& Peck), was introduced in order to predict potential financial distress in companies that do not belong to the industrial sector. Finally, authors in different countries have further modified the components of the original Z-score to adjust it to the specific characteristics of non-US economic systems and markets.

Note 2. There is not an unique mean to define company failure in economic literature. Altman (1968/1993) combines business failures in the U.S. with the applying for bankruptcy ex Chapter 11. Deakin (1972) considers not only this kind of "legal" bankruptcy but also a protract state of insolvency and a forced close-out for financial distress. In our opinion, the delisting from an official stock market (specifically from the Italian Stock Market-Borsa di Milano), or the permanent suspension from quotation, are useful and appropriate tools to ascertain a business failure.

Note 3. In the time period considered (1995-2013), the average number of delisted companies for each year is 2 ,8. It is interesting to point out that in the period 2010-2013 only, when the effects of the world financial crisis were particularly dramatic, the number of delisted companies went up to 20 .

\section{Copyrights}

Copyright for this article is retained by the author(s), with first publication rights granted to the journal.

This is an open-access article distributed under the terms and conditions of the Creative Commons Attribution license (http://creativecommons.org/licenses/by/3.0/). 